http://dx.doi.org/10.18778/1508-1117.26.06

Marcin Wójcik, Anna Traczyk

\title{
SPECJALIZACJA WOJEWÓDZTWA LÓDZKIEGO W PRODUKCJI ROŚLINNEJ I ZWIERZĘCEJ
}

\begin{abstract}
Zarys treści Specjalizacja w rolnictwie jest jednym z najważniejszych czynników rozwoju sektora rolnego we współczesnych warunkach gospodarowania. Nastawienie gospodarstw rolnych na wytwarzanie wąskiej grupy produktów umożliwia uzyskanie przez nie dużych i jednolitych partii towarów, pożądanych na rynku. Pozwala także na lepsze wykorzystanie maszyn i sprzętu w produkcji rolniczej oraz przyczynia się do wzrostu efektywności produkcji i zwiększenia dochodów gospodarstw rolnych.

Celem artykułu jest identyfikacja gałęzi specjalizacji produkcji roślinnej i zwierzęcej występujących w województwie łódzkim oraz określenie roli regionu łódzkiego w krajowej produkcji rolniczej.
\end{abstract}

Słowa kluczowe Rolnictwo, specjalizacja, województwo łódzkie.

\section{Wprowadzenie}

Specjalizacja gospodarstw rolnych jest jednym z najważniejszych czynników rozwoju sektora rolnego, zwłaszcza w warunkach rozdrobnionej struktury agrarnej i niskiej efektywności ekonomicznej indywidualnych gospodarstw rolnych (Smędzik 2010). Proces specjalizacji w rolnictwie polega na ograniczaniu liczby wytwarzanych produktów (uprawianych gatunków roślin lub hodowanych ras zwierząt) z jednoczesnym doskonaleniem sposobu ich wytwarzania. Gospodarstwa rolne zajmujące się wytwarzaniem wąskiej grupy produktów mogą coraz to bardziej doskonalić (specjalizować) sposób ich wytwarzania, osiągając lepszą jakość wytwarzanych produktów (Kulikowski 2003). Specjalizacja umożliwia przygotowanie dużych i jednolitych partii towaru, pożądanych przez odbiorców na rynku. Pozwala także na lepsze wykorzystanie maszyn i urządzeń w produkcji rolniczej (Wicki 2005). Specjalizacja w rolnictwie sprzyja wzrostowi efektywności produkcji i umożliwia wzrost dochodów gospodarstw rolnych, czym przyczynia się do poprawy sytuacji ekonomicznej gospodarstw (Smędzik 
2010). Zjawisko specjalizacji w rolnictwie może być rozpatrywane zarówno od strony kierunków specjalizacji (kierunków produkcji), a więc tego w czym dane gospodarstwo lub obszar się specjalizuje, jak i od strony stopnia specjalizacji, czyli w jakim stopniu dane gospodarstwo lub rolnictwo jakiegoś obszaru jest wyspecjalizowane (Szyrmer 1980).

Problematyka specjalizacji $\mathrm{w}$ rolnictwie stanowi przedmiot rozważań studiów ekonomiczno-rolniczych. Badania nad specjalizacją w rolnictwie prowadzili głównie ekonomiści rolni, m.in. Z. Wojtaszek, T. Dąbrowski, R. Manteuffel, J. Okuniewski, N. Kusze, W. Pytkowski, P. Dąbrowski, J.H Szyrmer (Kulikowski 2003). W geografii problematyka ta do niedawna rozpatrywana była w ramach oddzielnej dyscypliny naukowej - geografii rolnictwa. Studia nad specjalizacją rolnictwa w geografii prowadził m.in. R. Kulikowski ${ }^{1}$. Współcześnie zainteresowanie problematyką rolnictwa w geografii jest mniejsze. Rozwiązanie w 2001 roku Zakładu Geografii Rolnictwa i Obszarów Wiejskich w Instytucie Geografii i Przestrzennego Zagospodarowania Polskiej Akademii Nauk oraz spadek zainteresowania problemami rozwoju rolnictwa na skutek obniżenia jego znaczenia w gospodarce, spowodował stopniowe odchodzenie od tej problematyki (Wójcik 2012). Współcześnie kwestie związane z rolnictwem rozpatrywane są w ramach geografii wsi, dla której rolnictwo stanowi jeden z problemów badawczych (Bański 2007).

Celem artykułu jest identyfikacja gałęzi specjalizacji produkcji roślinnej i zwierzęcej występujących w województwie łódzkim oraz określenie roli województwa łódzkiego w krajowej produkcji rolniczej. W pracy skupiono się na analizie rozmieszczenia roślin uprawnych, w uprawie których województwo odgrywa znaczącą rolę w skali kraju (udział województwa w krajowej produkcji danej rośliny powyżej $10 \%$ ). Analizy rozmieszczenia produkcji roślinnej w województwie łódzkim dokonano w oparciu o iloraz lokalizacji - zestawiono udział procentowy danej kategorii rośliny uprawnej danej gminy w ogólnej powierzchni zajętej przez tę kategorię w Polsce $\mathrm{z}$ udziałem procentowym powierzchni zasiewów (w przypadku sadów - powierzchni użytków rolnych) danej gminy w ogólnej powierzchni zasiewów (w przypadku sadów - w powierzchni użytków rolnych) w Polsce. Im wyższa wartość wskaźnika tym wyższy poziom specjalizacji gminy w uprawie danej rośliny.

Przeanalizowano także rozmieszczenie hodowli trzody chlewnej, bydła i drobiu, w hodowli których województwo łódzkie zajmuje wysoką pozycję w skali kraju. Obszary koncentracji produkcji zwierzęcej wyodrębniono na podstawie obsady poszczególnych zwierząt gospodarskich na 100 ha użytków rolnych.

\footnotetext{
${ }^{1}$ Por. R. Kulikowski (2003).
} 


\section{Rola województwa lódzkiego w krajowej produkcji roślinnej i zwierzęcej}

Rolnictwo odgrywa ważną rolę w gospodarce województwa łódzkiego. O dużym znaczeniu rolnictwa w gospodarce regionu świadczy wysoki (wyższy niż średni w Polsce) udział użytków rolnych w całkowitej powierzchni województwa. W 2014 roku użytki rolne w województwie łódzkim zajmowały 52,6\% jego powierzchni (w Polsce 46,6\% powierzchni kraju), co plasowało województwo na szóstym miejscu w kraju pod względem udziału użytków rolnych w całkowitej powierzchni (BDL).

Region łódzki charakteryzuje się gorszymi niż przeciętne w kraju warunkami przyrodniczymi dla produkcji rolniczej (Suliborski 2001). Wskaźnik waloryzacji rolniczej przestrzeni produkcyjnej (WWRPP), obejmujący warunki wodne, rzeźbę terenu, agroklimat i jakość gleb dla województwa łódzkiego wynosi zaledwie 61,9 pkt, co plasuje je na trzecim miejscu od końca w skali kraju. Gorsze niż w regionie łódzkim warunki przyrodniczo-glebowe występują jedynie w województwie mazowieckim i podlaskim, gdzie wartość wskaźnika wynosi poniżej 60 pkt.

Województwo łódzkie pod względem przydatności warunków przyrodniczych dla produkcji rolniczej jest bardzo zróżnicowane. Najlepsze warunki dla produkcji roślinnej występują w jego północnej części (w powiecie kutnowskim, łęczyckim i w północno-zachodniej części powiatu łowickiego), gdzie wartość WWRPP wynosi powyżej 71,0 pkt (rys. 1). Korzystne dla produkcji rolniczej warunki przyrodnicze występują także w przeważającej części powiatu piotrkowskiego, sieradzkiego, wieluńskiego, skierniewickiego, rawskiego oraz łódzkiego wschodniego.

Najmniej sprzyjające produkcji rolniczej warunki przyrodnicze występują głównie w położonych na południu i południowym-wschodzie powiatach: wieruszowskim, pajęczańskim, radomszczańskim, opoczyńskim, bełchatowskim i tomaszowskim, gdzie wartość WWRPP wynosi poniżej 61 pkt. Mało korzystne dla produkcji rolniczej warunki naturalne występują także w przeważającej części powiatu poddębickiego, pabianickiego oraz zgierskiego (rys. 1).

Pomimo gorszych niż przeciętne w kraju warunków przyrodniczych dla prowadzenia działalności rolniczej, województwo łódzkie odgrywa ważną rolę w krajowej produkcji roślinnej. Region łódzki jest czołowym producentem ziemniaków w Polsce. Jest liczącym się w skali kraju producentem żyta, owoców, warzyw gruntowych oraz mieszanek zbożowych, w produkcji których jego udział wynosi powyżej 10\%. Odgrywa także ważną rolę w krajowej produkcji pszenżyta, ziaren słonecznika, owsa oraz kukurydzy. Niewielką rolę odgrywa natomiast w produkcji roślin strączkowych, buraków cukrowych, pszenicy oraz roślin oleistych. Udział województwa w produkcji wymienionych roślin wynosi poniżej 5\% (rys. 2). 


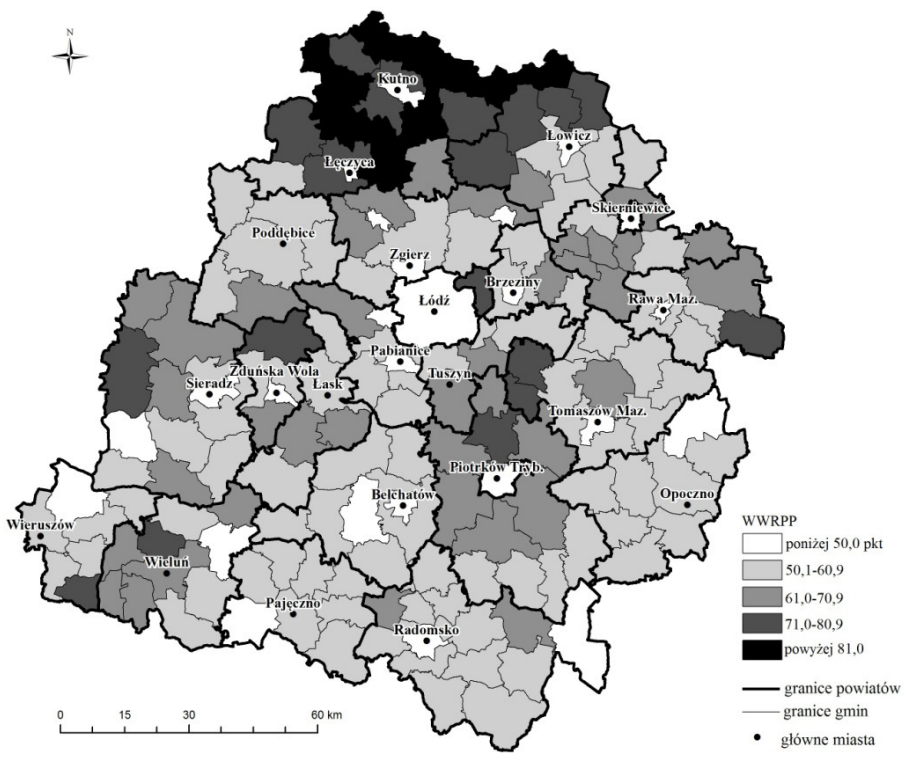

Rys. 1. Wskaźnik waloryzacji rolniczej przestrzeni produkcyjnej Źródło: Potencjat rozwojowy obszarów wiejskich (2014)

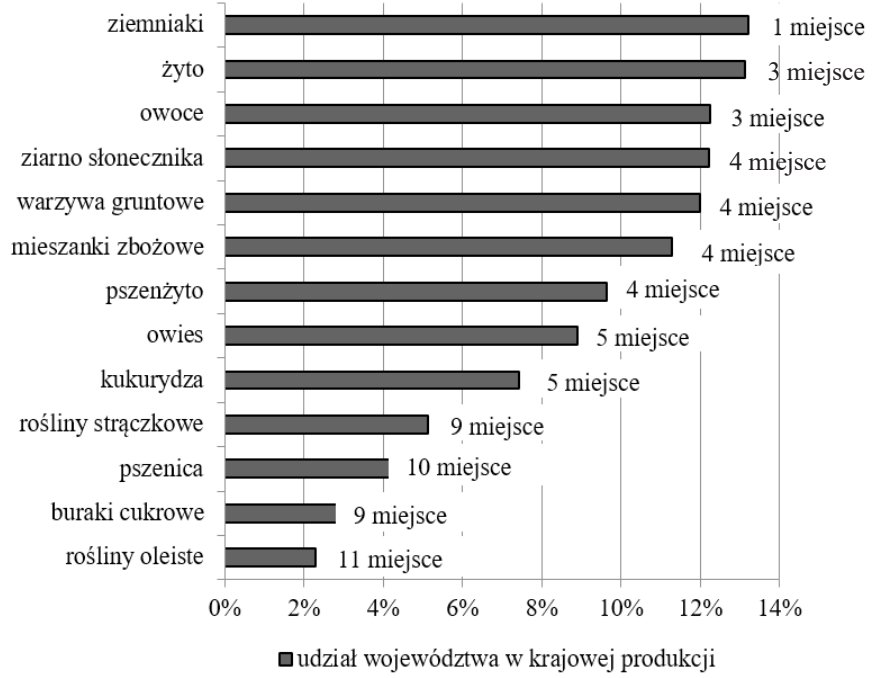

Rys. 2. Udział i pozycja województwa łódzkiego w krajowej produkcji roślinnej w 2014 roku

Źródło: opracowanie własne na podstawie danych BDL 
Województwo łódzkie jest liczącym się w skali kraju hodowcą trzody chlewnej, bydła oraz drobiu. W 2014 roku zajmowało 3. miejsce pod względem obsady trzody chlewnej, 4. miejsce pod względem obsady bydła oraz 5. pod względem obsady drobiu na 100 ha użytków rolnych. Niewielką rolę odgrywa w hodowli pozostałych zwierząt gospodarskich, tj. owiec, kóz, koni i indyków.

\section{Specjalizacja województwa lódzkiego w produkcji roślinnej}

Region łódzki odgrywa istotną rolę w krajowej produkcji roślinnej. Jednym z najważniejszych kierunków jego specjalizacji jest produkcja ziemniaków.

Ziemniaki ze względu na niewielkie wymagania klimatyczno-glebowe oraz możliwość szerokiego wykorzystania zarówno do celów konsumpcyjnych, jak i przemysłowych odgrywają znaczącą rolę w strukturze produkcji rolniczej województwa łódzkiego. W latach 2000-2014 areał upraw ziemniaków w województwie łódzkim uległ znacznemu ograniczeniu. W 2000 roku w regionie łódzkim ziemniaki uprawiano na 156326 ha powierzchni, natomiast w 2014 roku już tylko na 34960 ha (spadek o 77,6\%). Wraz z ograniczeniem areału upraw, znacznemu spadkowi uległa również wielkość produkcji ziemniaków. W 2000 roku w województwie zebrano ich łącznie 2955225 ton, natomiast w 2014 roku wielkość zbiorów była o 65,6\% niższa w stosunku do roku 2000 i wynosiła 1016410 ton (BDL). Przyczyną spadku powierzchni zajmowanej przez uprawy ziemniaków, a tym samym ograniczenia wielkości ich produkcji jest przede wszystkim odchodzenie od produkcji ziemniaków na cele paszowe oraz spadek pogłowia trzody chlewnej, dla której ziemniaki do niedawna stanowiły podstawowy składnik żywieniowy (Nowacki 2013). Zarówno pod względem powierzchni zajmowanej przez uprawy ziemniaków, jak i wielkości ich produkcji w 2014 roku obszar ten zajmował 1. miejsce w kraju, a jego udział w krajowej produkcji wynosił 13,2\% (BDL).

Uprawa ziemniaków w regionie łódzkim skupia się głównie w jego zachodniej i południowej części. Obszarami o najwyższej koncentracji upraw ziemniaków w regionie jest powiat sieradzki oraz gminy: Pęczniew, Zadzim (powiat poddębicki), Sokolniki, Czastary (powiat wieruszowski), Biała, Czarnożyły, Wieluń, Pątnów, Wierzchlas (powiat wieluński), Wielgomłyny, Kodrąb, Radomsko (powiat radomszczański), Sadkowice, Regnów, Cielądz (powiat rawski), miasto i gmina Skierniewice oraz miasto Zgierz i Łęczyca (rys. 3).

Drugim ważnym kierunkiem specjalizacji produkcji roślinnej w regionie jest produkcja sadownicza. Sadownictwo jest gałęzią rolnictwa obejmującą uprawę roślin trwałych (wieloletnich) dających jadalne owoce w sadach oraz na plantacjach (Encyklopedia Popularna PWN 2006). Podstawową funkcją sadownictwa jest dostarczanie produktów żywnościowych w postaci owoców o zróżnicowanych walorach odżywczych, smakowych i zdrowotnych (Kubiak 1998). 


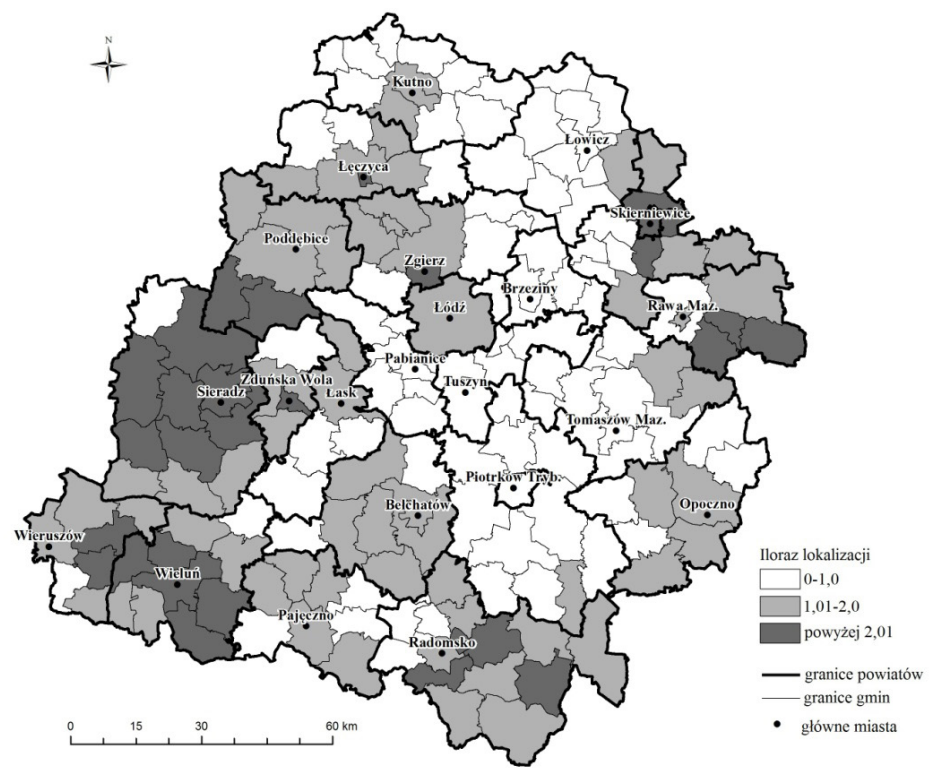

Rys. 3. Rozmieszczenie upraw ziemniaków w województwie łódzkim w 2010 roku Źródło: opracowanie własne na podstawie danych PSR 2010

W latach 2000-2014 powierzchnia zajmowana przez sady w województwie łódzkim systematycznie zwiększała się. W 2000 roku sady zajmowały 25493 ha powierzchni, natomiast w 2014 roku 36656 ha (BDL). W strukturze uprawianych drzew owocowych w regionie łódzkim dominują jabłonie, których uprawa stanowi $70 \%$ powierzchni upraw drzew owocowych w regionie. Dużą rolę w strukturze upraw odgrywają także wiśnie oraz śliwy, natomiast niewielką grusze i czereśnie. Wśród roślin jagodowych największą powierzchnię zajmują porzeczki oraz truskawki i poziomki (rys. 4).

Wraz ze wzrostem areału sadów wzrosła także ilość produkowanych owoców. W 2000 roku w województwie łódzkim zebrano w sumie 212 tys. ton owoców, natomiast w 2014 roku 512 tys. ton (BDL).

Region łódzki jest jednym z liderów w produkcji owoców w Polsce. W 2014 roku obszar ten zajmował 3. miejsce pod względem wielkości zbiorów owoców z drzew owocowych i plantacji jagodowych. Udział województwa łódzkiego w krajowej produkcji owoców wynosi 12,2\% (BDL).

Produkcja sadownicza w województwie łódzkim koncentruje się głównie w jego wschodniej części, na obszarze powiatu: skierniewickiego, rawskiego, łowickiego, wschodniej części powiatu zgierskiego oraz północno-wschodniej części powiatu brzezińskiego (rys. 5). 

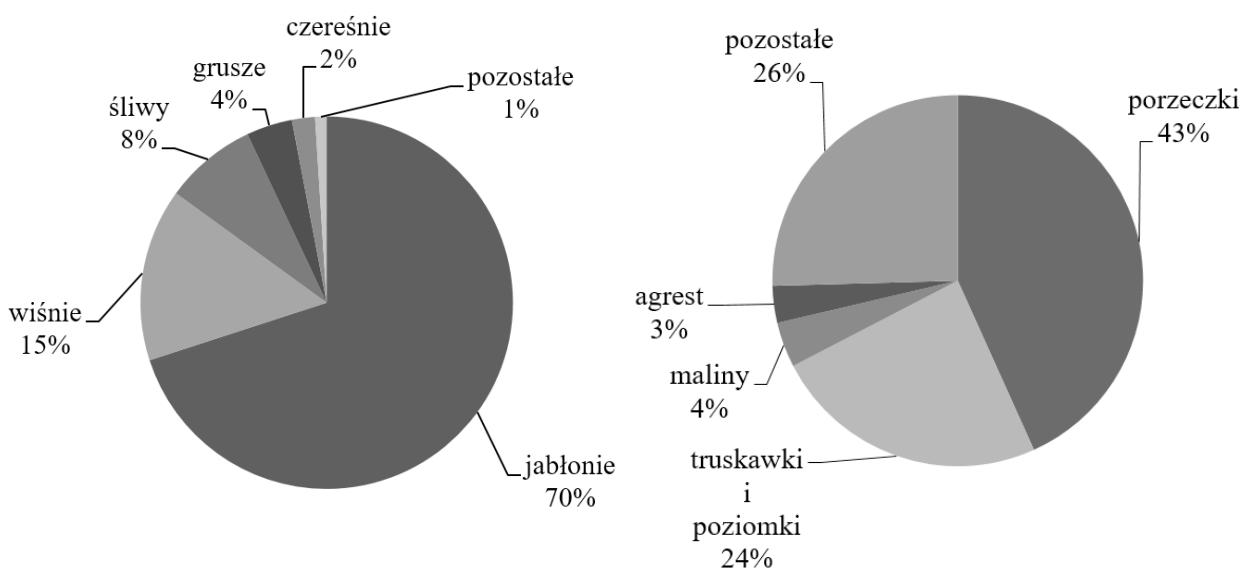

Rys. 4. Struktura upraw drzew owocowych i roślin jagodowych

w województwie łódzkim w 2014 roku

Źródło: opracowanie własne na podstawie: Produkcja upraw rolnych i ogrodniczych w 2014 r., GUS

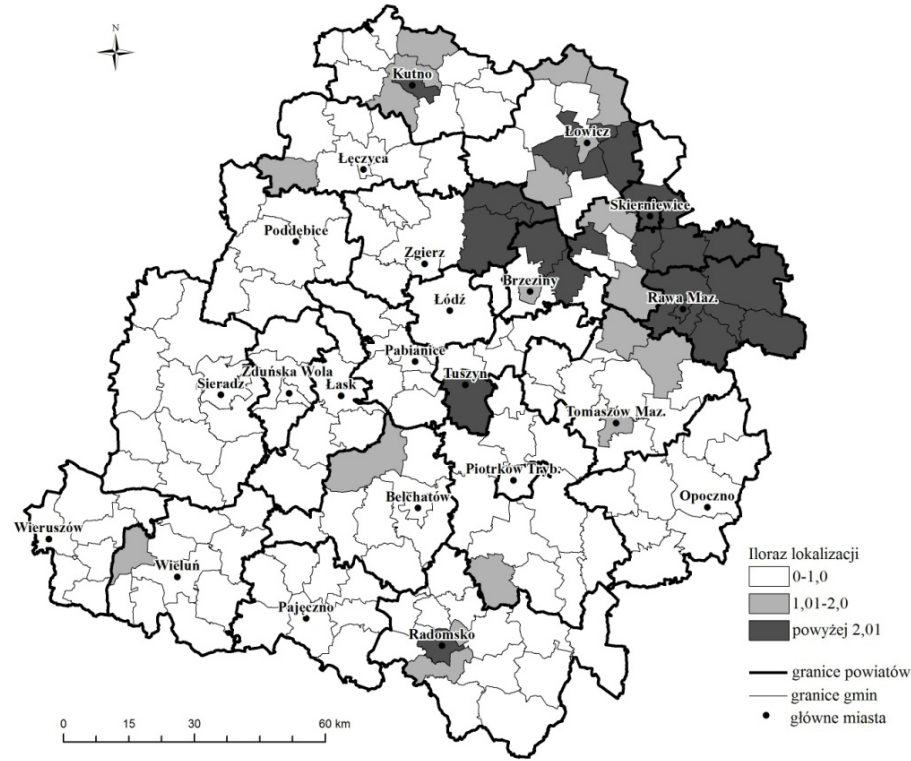

Rys. 5. Rozmieszczenie sadów w województwie łódzkim w 2010 roku Źródło: opracowanie własne na podstawie danych PSR 2010 
Kolejnym kierunkiem specjalizacji województwa łódzkiego w produkcji roślinnej jest produkcja warzyw gruntowych. Warzywa gruntowe to rośliny uprawiane bezpośrednio w gruncie lub pod niskimi osłonami, których wysokość w szczycie nie przekracza $1,5 \mathrm{~m}$.

Do warzyw gruntowych należą m.in. kapusta, kalafior, cebula, marchew, buraki ćwikłowe, ogórki gruntowe, pomidory gruntowe, pietruszka, por, seler, rzodkiew, sałata oraz rabarbar (Uprawy ogrodnicze 2010).

W latach 2000-2014 powierzchnia zajmowana przez uprawy warzyw gruntowych w województwie łódzkim systematycznie zmniejszała się. W 2000 roku w regionie łódzkim warzywa uprawiano na 25237 ha powierzchni, natomiast w 2014 roku na areale o 6734 ha mniejszym. Pomimo spadku powierzchni zajmowanej przez uprawy warzyw gruntowych, wielkość produkcji warzyw na opisywanym obszarze utrzymuje się niemal na stałym poziomie. W 2000 roku wyprodukowano łącznie 566147 ton warzyw gruntowych, natomiast w 2014 roku 555738 ton. Pod względem produkcji warzyw gruntowych województwo łódzkie zajmuje 4. miejsce w Polsce. Jego udział w krajowej produkcji warzyw wynosi 11,9\% (BDL).

Największy udział w strukturze upraw warzyw gruntowych w regionie mają kapusta, ogórki gruntowe, marchew oraz cebula. Znacznie mniejszą powierzchnię zajmują uprawy buraków ćwikłowych, kalafiorów oraz pomidorów gruntowych, które zajmują poniżej 7\% powierzchni upraw warzyw gruntowych (rys. 6).

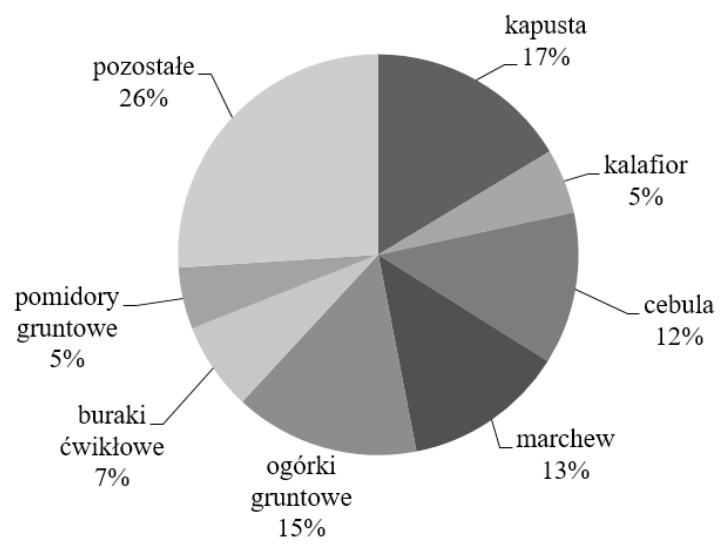

Rys. 6. Struktura upraw warzyw gruntowych w województwie łódzkim w 2014 roku Źródło: opracowanie własne na podstawie: Produkcja upraw rolnych i ogrodniczych w $2014 \mathrm{r}$., GUS

Warzywa są roślinami wymagającymi odpowiednich warunków do uprawy, dlatego ich uprawa koncentruje się głównie w północnej części województwa - obszarze o najwyżej wartości wskaźnika waloryzacji rolniczej przestrzeni produkcyjnej. Warzywnictwo odgrywa także istotą rolę w produkcji roślinnej w powiecie wieluńskim, pajęczańskim, sieradzkim i rawskim (rys. 7). 


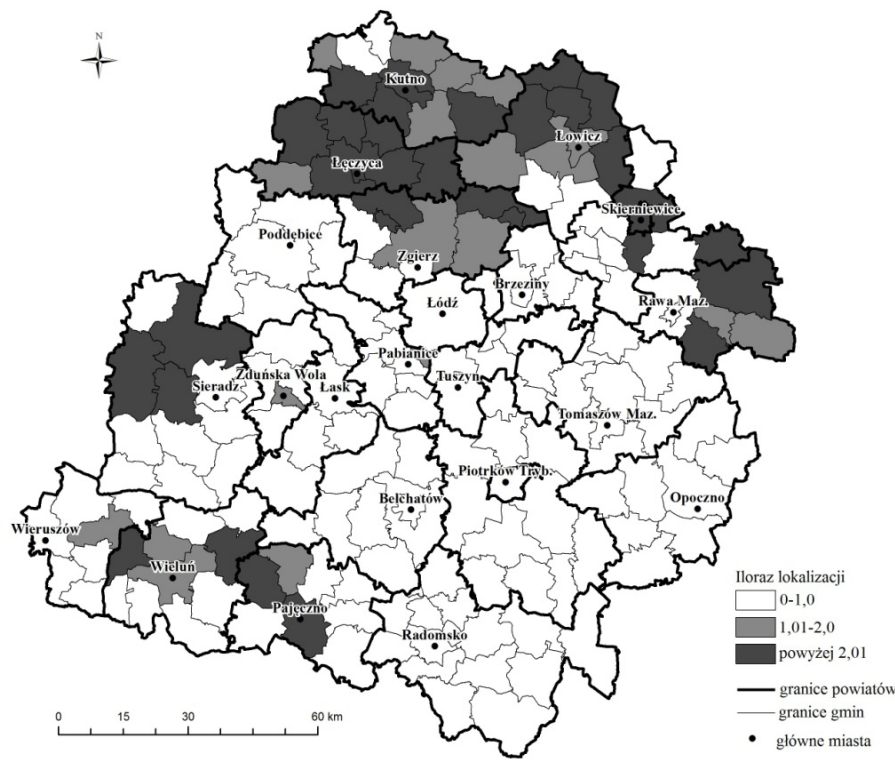

Rys. 7. Rozmieszczenie upraw warzyw gruntowych w województwie łódzkim w 2010 roku

Źródło: opracowanie własne na podstawie danych PSR 2010

Ważnym kierunkiem specjalizacji województwa łódzkiego w produkcji roślinnej jest uprawa żyta. Zboże to ze względu na niewielkie wymagania glebowe jest rośliną powszechnie uprawianą $\mathrm{w}$ województwie łódzkim. Jego udział w powierzchni zasiewów zbóż w regionie wynosi 23,1\% (BDL).

W latach 2000-2014 powierzchnia zajmowana przez uprawy żyta w województwie łódzkim systematycznie zmniejszała się. W 2000 roku w regionie łódzkim żyto uprawiano na 281533 ha powierzchni, natomiast w 2014 roku na 127762 ha (BDL). W analizowanym okresie powierzchnia upraw żyta zmniejszyła się o 54,6\%. Wraz ze spadkiem powierzchni zajmowanej przez uprawy żyta znacznemu ograniczeniu uległa także wielkość zbiorów. W 2000 roku w regionie łódzkim zebrano 496053 ton żyta, natomiast w 2014 roku 366993 ton (BDL). Przyczyną spadku znaczenia żyta $\mathrm{w}$ produkcji roślinnej w analizowanym okresie było częściowe zastąpienie jego uprawy zbożami dającymi wyższe plony, takimi jak pszenica, jęczmień, pszenżyto czy mieszanki zbożowe (Kulikowski 2013). Również spadek zużycia żyta na cele paszowe oraz malejące pogłowie trzody chlewnej wpłynęło na ograniczenie wielkości produkcji żyta (Rynek zbóż $w$ Polsce 2013).

Pomimo spadku wielkości produkcji żyta, województwo łódzkie jest liczącym się w skali kraju jego producentem. W 2014 roku zajmowało trzecie miejsce 
pod względem wielkości produkcji żyta, zaraz za województwem wielkopolskim i mazowieckim, a jego udział w krajowych zbiorach wynosił 13,1\% (BDL).

Żyto uprawiane jest praktycznie we wszystkich powiatach województwa łódzkiego, z wyjątkiem powiatu kutnowskiego, północnej części powiatu piotr-kowskiego i przeważającej części powiatu łódzkiego wschodniego. Obszarami o najwyższej koncentracji upraw żyta są powiaty: poddębicki, sieradzki, zduńskowolski, łaski, wieruszowski, pajęczański, radomszczański, bełchatowski oraz opoczyński (rys. 8).

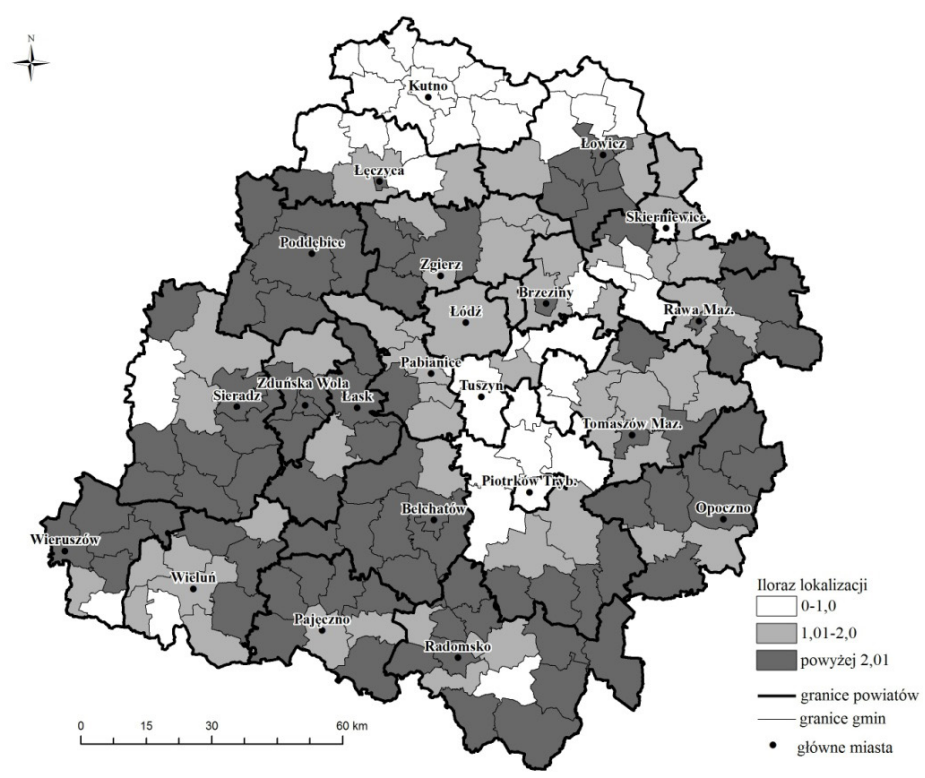

Rys. 8. Rozmieszczenie upraw żyta w województwie łódzkim w 2010 roku

Źródło: opracowanie własne na podstawie danych PSR 2010

Region łódzki specjalizuje się także w uprawie mieszanek zbożowych, które podobnie jak żyto odgrywają ważną rolę w strukturze zasiewów na opisywanym obszarze. Ich udział w strukturze zasiewów zbóż w 2014 roku wynosił 18,8\% (BDL). Mieszanki zbożowe uprawiane są wyłącznie na cele paszowe.

W latach 2000-2014 powierzchnia zajmowana przez uprawy mieszanek zbożowych w województwie łódzkim uległa znacznemu ograniczeniu. W 2000 roku mieszanki zbożowe uprawiano na 112756 ha, natomiast w 2014 roku na 97269 ha. Powierzchnia upraw mieszanek zbożowych $\mathrm{w}$ regionie $\mathrm{w}$ analizowanym okresie zmniejszyła się o 13,7\%. Wielkość zbiorów mieszanek zbożowych w województwie łódzkim wahała się w graniach 230-460 tys. ton (BDL). 
Region łódzki jest liczącym się w skali kraju producentem mieszanek zbożowych. W 2014 roku pod względem wielkości produkcji mieszanek zbożowych zajmował 4. miejsce wśród województw, zaraz za województwem podlaskim, mazowieckim i wielkopolskim, a jego udział w krajowej produkcji wynosił 11,3\% (BDL).

Mieszanki zbożowe uprawiane są w większości powiatów województwa łódzkiego. Obszarami o najwyższej koncentracji tych upraw w regionie są powiaty: pabianicki, łódzki wschodni, bełchatowski, piotrkowski i tomaszowski (rys. 9).

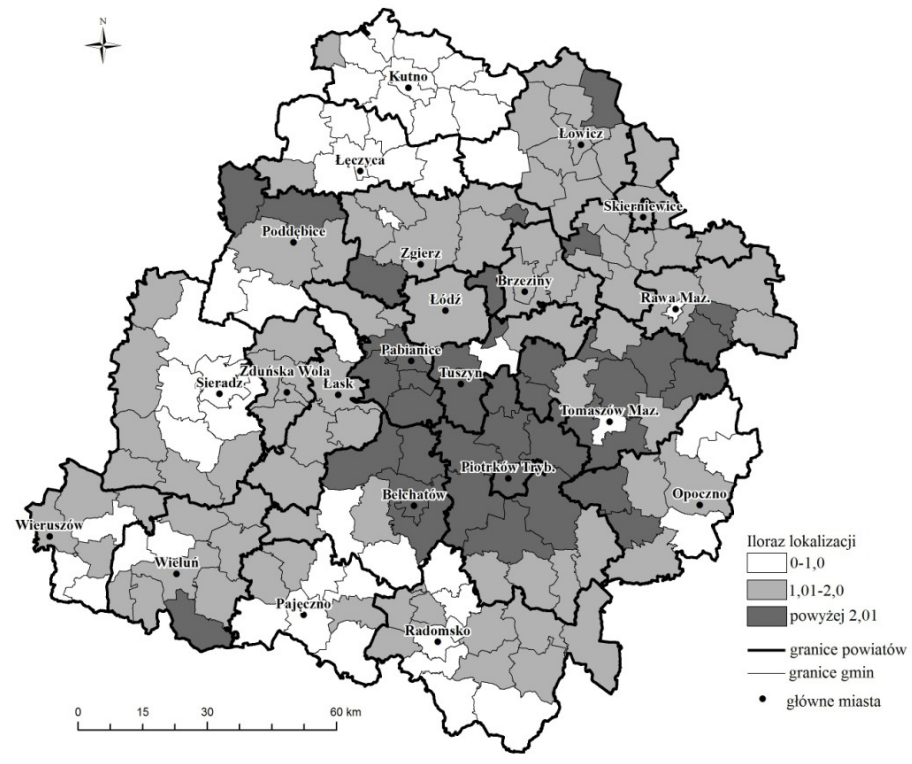

Rys. 9. Rozmieszczenie upraw mieszanek zbożowych w województwie łódzkim w 2010 roku

Źródło: opracowanie własne na podstawie danych PSR 2010

\section{Specjalizacja województwa lódzkiego w produkcji zwierzęcej}

Dominującym kierunkiem specjalizacji produkcji zwierzęcej w regionie łódzkim jest hodowla trzody chlewnej. W latach 2000-2014 wielkość pogłowia trzody chlewnej w województwie uległa zmniejszeniu. W 2000 roku na opisywanym obszarze hodowano 1190 tys. szt. trzody chlewnej, natomiast w 2014 roku 982 tys. szt. W analizowanym okresie wielkość pogłowia trzody chlewnej zmniejszyła się o 17,4\% (BDL). Przyczyną ograniczenia hodowli trzody chlewnej była niska opłacalność produkcji wynikająca z wysokich cen zbóż i pasz w porównaniu do cen uzyskiwanych ze sprzedaży żywca wieprzowego (Pejsak 2012). 
Hodowla trzody chlewnej koncentruje się zasadniczo na obszarze powiatu skierniewickiego, brzezińskiego, rawskiego, łódzkiego wschodniego, tomaszowskiego oraz piotrkowskiego (rys. 10).

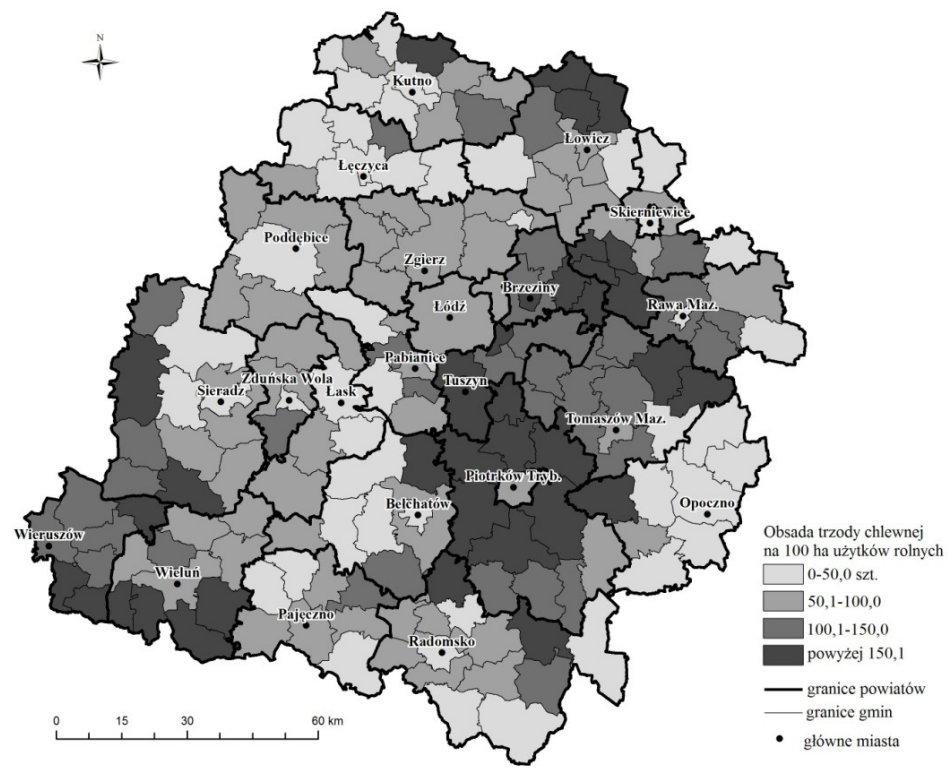

Rys. 10. Obsada trzody chlewnej w gminach województwa łódzkiego w 2010 roku Źródło: opracowanie własne na podstawie danych PSR 2010

Trzoda chlewna hodowana jest w celu uzyskania mięsa. W latach 2000-2014 wielkość produkcji żywca rzeźnego wieprzowego, podobnie jak wielkość pogłowia, wykazywała tendencję spadkową. Wielkość produkcji w analizowanym okresie w województwie łódzkim wahała się w graniach 203-312 tys. ton. Pomimo spadku wielkości pogłowia trzody chlewnej, obszar ten jest jednym z liderów w Polsce pod względem obsady trzody chlewnej i wielkości produkcji żywca rzeźnego wieprzowego. Wielkość obsady trzody chlewnej w regionie łódzkim wynosi 102,6 szt./100 ha użytków rolnych, co plasuje go na trzecim miejscu w kraju. W 2014 roku w województwie łódzkim wyprodukowano 259073 ton mięsa wieprzowego, co stanowiło $11 \%$ krajowej jego produkcji (BDL).

Drugim ważnym kierunkiem specjalizacji produkcji zwierzęcej w regionie jest hodowla bydła. Bydło hodowane jest przede wszystkim w celu pozyskania mięsa i mleka. Do niedawna istotnym z punktu widzenia produkcji rolniczej produktem chowu bydła był także obornik, wykorzystywany do użyźniania słabych gleb. Współcześnie, ze względu na powszechne stosowanie bezściółkowego systemu chowu zwierząt, produkcja obornika uległa znacznemu ograniczeniu. Również 
jego jakość uległa pogorszeniu, dlatego obornik nie jest już tak powszechnie stosowanym w rolnictwie nawozem (Kulikowski 2013).

W latach 2000-2014 wielkość pogłowia bydła w województwie łódzkim wahała się w graniach 413-486 tys. szt. (w Polsce 5 200-5 723 tys. szt.). W 2014 roku region łódzki zajmował 4. miejsce wśród województw pod względem wielkości obsady bydła przypadającej na 100 ha użytków rolnych. Wielkość pogłowia bydła na opisywanym obszarze wynosiła 46,7 szt./100 ha użytków rolnych (BDL). Wyższym niż notowane w województwie łódzkim pogłowiem bydła charakteryzowały się województwa: podlaskie ( 87,1 szt./100 ha użytków rolnych), mazowieckie (55,4 szt./100 użytków rolnych) oraz wielkopolskie (49,2 szt./100 ha użytków rolnych).

Hodowla bydła koncentruje się w północnej i zachodniej części regionu łódzkiego. Obszarami o najwyższej obsadzie bydła na 100 ha użytków rolnych są powiaty: łowicki, łęczycki, poddębicki i sieradzki (rys. 11).

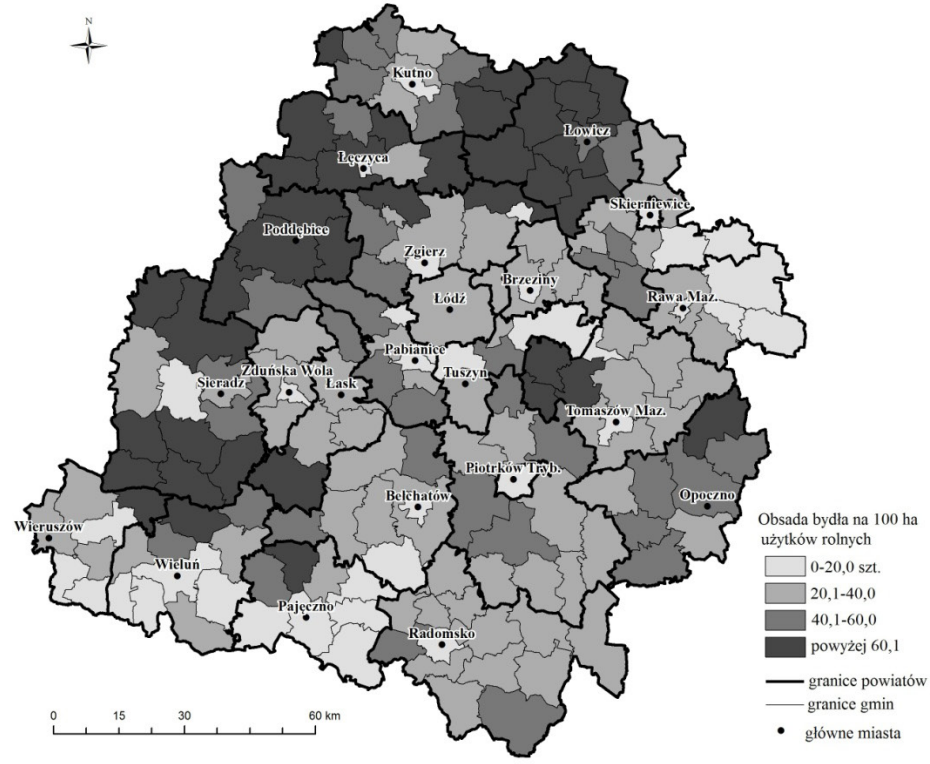

Rys. 11. Obsada bydła w gminach województwa łódzkiego w 2010 roku Źródło: opracowanie własne na podstawie danych PSR 2010

Pod względem wielkości produkcji żywca rzeźnego wołowego i cielęcego oraz mleka, województwo łódzkie w 2014 roku zajmowało 4. miejsce w kraju. Jego udział w krajowej produkcji żywca rzeźnego wołowego i cielęcego wynosił $11 \%$, natomiast w produkcji mleka $8 \%(\mathrm{BDL})$. 
Istotnym kierunkiem specjalizacji produkcji zwierzęcej na opisywanym obszarze jest hodowla drobiu. Drób hodowany jest w celu pozyskania mięsa i jaj. Na potrzeby produkcji jaj hoduje się przede wszystkim kury, natomiast z przeznaczeniem na mięso hoduje się kury, gęsi, kaczki i indyki (Olszewski 1985).

W latach 2005-2014 wielkość pogłowia drobiu w województwie łódzkim utrzymywała się na zbliżonym poziomie wynoszącym średnio 10765 tys. szt. W strukturze hodowli drobiu dominuje drób kurzy, który stanowi 95\% wszystkich gatunków drobiu hodowanych w województwie. Około 3\% stanowią kaczki, 2\% gęsi, a 1\% indyki. W 2014 roku województwo łódzkie zajmowało 5. miejsce pod względem obsady drobiu na 100 ha użytków rolnych (średnio 1056,5 szt./ 100 ha użytków rolnych). Pod względem obsady gęsi obszar ten zajmował 1. miejsce $\mathrm{w}$ kraju, $\mathrm{z}$ obsadą 20,7 szt./100 ha użytków rolnych, natomiast pod względem obsady kaczek 3. miejsce wśród województwa z obsadą 34,6 szt./100 ha użytków rolnych (BDL).

Hodowla drobiu w regionie skupia się w jego północnej i środkowej części. Obszarami o najwyższej koncentracji hodowli drobiu są powiaty: kutnowski, łowicki, zgierski, skierniewicki, tomaszowski, pabianicki oraz w dużej części także powiaty: brzeziński, rawski, piotrkowski, łaski, zduńskowolski oraz miasto Łódź (rys. 12).

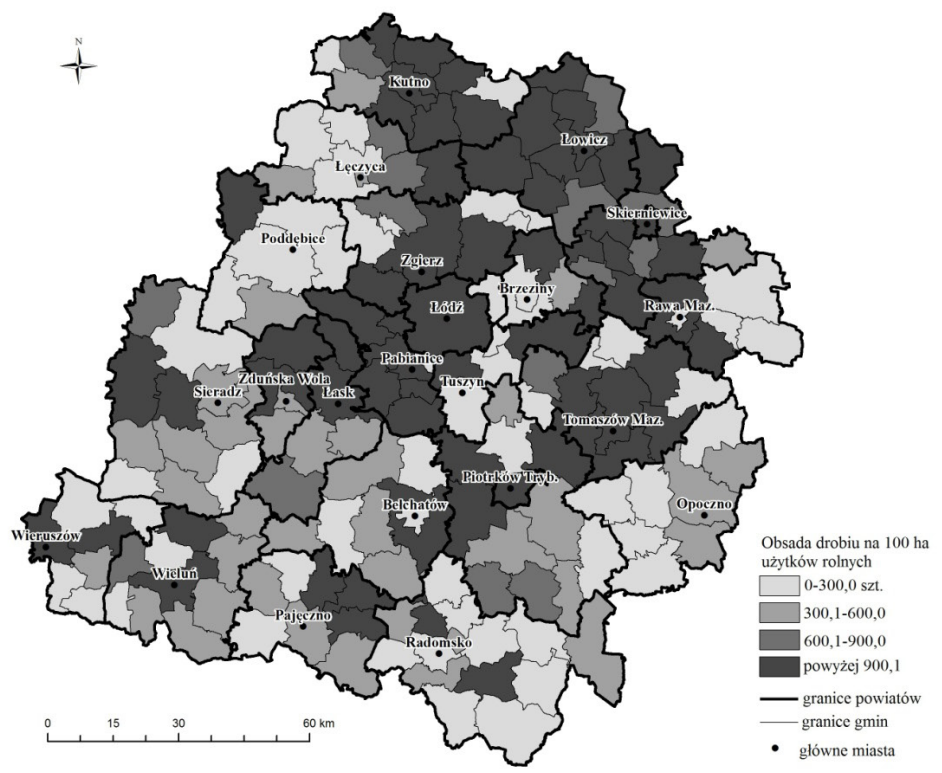

Rys. 12. Obsada drobiu w gminach województwa łódzkiego w 2010 roku Źródło: opracowanie własne na podstawie danych PSR 2010 
Województwo łódzkie odgrywa ważną rolę w produkcji drobiu w Polsce. Jego udział w krajowej produkcji żywca rzeźnego drobiowego wynosi 7,3\%, co plasuje województwo na 5. miejscu w kraju. Pod względem wielkości produkcji jaj opisywany obszar zajmuje 3. miejsce w kraju. W 2014 roku w województwie wyprodukowano ich ponad 767 tys. sztuk (BDL).

\section{Podsumowanie}

Rolnictwo jest ważnym sektorem gospodarki w województwie łódzkim. O rolniczym charakterze regionu świadczy m.in. wysoki (wyższy niż średni w Polsce) udział użytków rolnych w powierzchni ogólnej regionu.

Województwo łódzkie ma znaczący udział w krajowej produkcji zarówno roślinnej, jak i zwierzęcej. Region ten specjalizuje się w produkcji ziemniaków, których jest największym producentem w Polsce, warzyw gruntowych, owoców, żyta oraz mieszanek zbożowych. Jest również liczącym się w skali kraju producentem owsa, pszenżyta i ziaren słonecznika. Odgrywa także ważną rolę w krajowej produkcji zwierzęcej. Województwo łódzkie specjalizuje się w hodowli trzody chlewnej, bydła i drobiu. Zajmuje wysoką pozycję wśród województw zarówno pod względem obsady zwierząt gospodarskich na 100 ha użytków rolnych, jak i pod względem wielkości produkcji żywca rzeźnego, mleka i jaj.

Rozmieszczenie produkcji roślinnej na opisywanym obszarze wykazuje silne powiązanie z warunkami przyrodniczymi. W północnej części województwa, gdzie występują najlepsze warunki dla produkcji rolniczej i gdzie wskaźnik waloryzacji rolniczej przestrzeni produkcyjnej jest najwyższy w regionie skupia się produkcja warzyw gruntowych, których uprawa wymaga dobrych warunków przyrodniczych. W północno-wschodniej i wschodniej części województwa, na obszarach o wysokim wskaźniku waloryzacji rolniczej przestrzeni produkcyjnej, koncentruje się produkcja sadownicza. Żyto ze względu na niewielkie wymagania glebowe uprawiane jest na obszarach o niskim wskaźniku waloryzacji rolniczej przestrzeni produkcyjnej. Uprawa mieszanek zbożowych natomiast jest ważnym kierunkiem produkcji roślinnej w gminach położonych na wschód i południe od Łodzi. Obszary te charakteryzują się także najwyższą w województwie obsadą trzody chlewnej na 100 ha użytków rolnych. Mieszanki zbożowe stanowią podstawowy składnik żywieniowy trzody chlewnej, dlatego też gminy charakteryzujące się wysoką obsadą trzody chlewnej na 100 ha użytków rolnych cechują się także dużym udziałem mieszanek zbożowych w strukturze użytków rolnych. Hodowla bydła skupia się w zachodniej i północno-wschodniej części regionu, natomiast drobiu w środkowej i północnej części województwa.

Województwo łódzkie, pomimo gorszych niż przeciętne w kraju warunków przyrodniczych dla funkcjonowania rolnictwa, odgrywa ważną rolę w krajowej produkcji rolniczej. Dzięki wysokiemu udziałowi kilku produktów bazy żywnościowej Polski jest jednym z ważniejszych w kraju obszarów produkcji rolnej. 


\section{LITERATURA}

Bański J., 2007, Geografia rolnictwa Polski, Polskie Wydawnictwo Ekonomiczne, Warszawa.

Encyklopedia Popularna PWN, 2006, Warszawa.

Kubiak K., 1998, Ekonomika i organizacja gospodarstw ogrodniczych, cz. 1, Wydawnictwa Szkolne i Pedagogiczne, Warszawa.

Kulikowski R., 2003, Syntetyczne metody badań produktywności i towarowości rolnictwa. Zastosowania w badaniach geograficznych w Polsce, „Prace Geograficzne”, 187.

Kulikowski R., 2013, Produkcja i towarowość rolnictwa w Polsce. Przemiany i zróżnicowanie przestrzenne po II wojnie światowej, IGiPZ PAN, Warszawa.

Nowacki W., 2013, O naprawie rynku ziemniaka w Polsce, „Ziemniak Polski”, 3.

Olszewski T., 1985, Geografia rolnictwa Polski, Państwowe Wydawnictwo Ekonomiczne, Warszawa.

Pejsak Z., 2012, Przyczyny gwałtownego spadku pogłowia trzody chlewnej w Polsce, „Trzoda Chlewna”, 50 (3).

Potencjał rozwojowy obszarów wiejskich, 2014, BPP WŁ, Łódź.

Powszechny Spis Rolny 2010, GUS, Warszawa.

Produkcja upraw rolnych i ogrodniczych w 2014 r., GUS.

Rynek zbóż w Polsce, 2013, ARR.

Smędzik K., 2010, Skala produkcji a efektywność różnych typów indywidualnych gospodarstw rolnych $w$ Polsce z zastosowaniem modeli DEA, „Roczniki Ekonomiczne Kujawsko-Pomorskiej Szkoły Wyższej w Bydgoszczy", 3.

Suliborski A., 2001, Gospodarka rolna, [w:] Liszewski S. (red.), Funkcja regionalna Łodzi i jej rola w kształtowaniu województwa. Zarys monografii województwa łódzkiego, ŁTN, Łódź.

Szyrmer J.H., 1980, Przemiany struktury przestrzennej produkcji towarowej rolnictwa indywidualnego w Polsce w latach 1960-1970, „Prace Geograficzne”, 134.

Uprawy ogrodnicze, Powszechny Spis Rolny 2010, GUS, Warszawa.

Wicki L., 2005, Dynamika i efekty ukierunkowania gospodarstw rolniczych, [w:] Kłodziński M., Dzun W. (red.), Rolnictwo a rozwój obszarów wiejskich, IRWiR PAN, Wydział Ekonomiki i Organizacji Gospodarki Żywnościowej Akademii Rolniczej w Szczecinie, Katedra Rozwoju Obszarów Wiejskich i Gospodarki Żywnościowej, Warszawa.

Wójcik M., 2012, Geografia wsi w Polsce. Studium zmiany podstaw teoretyczno-metodologicznych, Wydawnictwo Uniwersytetu Łódzkiego, Łódź.

\section{SPECIALIZATION OF THE ŁÓDŹ VOIVODESHIP IN PLANT AND LIVESTOCK PRODUCTION}

Abstract Specialization in agriculture is one of the most important factors in the development of the agricultural sector in today's farming conditions. Focusing the farms on the production of a small group of products allows for their large, uniform batches of goods, desired by the market. Specialization in agriculture 
also allows better exploitation of machinery and equipment for agricultural production, and contributes to increasing the efficiency of production and the farm incomes.

Agriculture is an important sector of the economy in Łódź voivodeship. Despite the very favorable natural conditions for agricultural production, Łódź voivodeship is typically agricultural. The agricultural nature of the area is mainly evidenced by the high (higher than the average in Poland) share of agricultural land in the total area of the voivodeship.

Łódź voivodeship has a large share in domestic production of both livestock and plant. Łódź voivodeship specializes in the production of potatoes, which is the biggest producer in Poland, and also in the production of field vegetables, fruits, wheat and cereal mixtures. It is also a major nationwide producer of oats, triticale and sunflower seeds. It also plays an important role in the domestic livestock production. Łódź voivodeship specializes in the breeding of pigs, cattle and poultry. It ranks high among the voivodships in terms of density of livestock per 100 ha of agricultural land as well as in terms of production of livestock for slaughter, milk and eggs.

Despite the worse than average in the country's natural conditions for the functioning of agriculture, Łódź voivodeship plays an important role in domestic agricultural production. Thanks to the high participation of several products in the creation of the Polish food base, it is one of the most important agricultural regions in the country.

Keywords Agriculture, specialization, the Łódź Region.

Dr hab. Marcin Wójcik, prof. UŁ Mgr Anna Traczyk Katedra Geografii Regionalnej i Społecznej Wydział Nauk Geograficznych Uniwersytet Łódzki 